\title{
The Use of Multi-source Satellite and Geospatial Data to Study the Effect of Urbanization on Primary Productivity in the United States
}

M. L. Imhoff, C. J. Tucker, W. T. Lawrence, D. C. Stutzer, and R. J. Rusin

\begin{abstract}
Data from two different satellites, a digital land cover map, and digital census data were analyzed and combined in a geographic information system to study the effect of (vegetatic.1)

urbanization on photosyntheticpproductivity in the United States. Results show that urbanization can have a measurable but variable impact on the primary productivity of the land surface. Annual productivity can be reduced by as much as 20 days in some areas, but in resource limited regions, photosynthetic production can be enhanced by human activity. Overall, urban development reduces the productivity of the land surface and those areas with the highest productivity are directly in the path of urban sprawl.
\end{abstract}




\section{INTRODUCTION}

As we begin to recognize the scope of human influence on Earth's ecosystems, it is important to understand how specific forms of human induced land transformation affect the dynamics of Earth's biological systems. Land transformation due to human activity has taken many forms historically starting with fire management, herding practices, the development of agriculture, and culminating with urbanization including industrial development [1-3]. Past studies of human impacts to the biosphere estimate that between one third to one half of the planet's land surface has been transformed by human action [4] and that nearly $40 \%$ percent of the yearly products of photosynthesis are appropriated by human beings [5]. Recently, more attention is being paid to urbanization as it constitutes one of the more ecologically disturbing land transformation processes and urban areas are expanding rapidly as human populations grow in size, affluence, and technological capability [6-9].

While there are numerous issues that could be addressed concerning urbanization, in this study we focus specifically on how urbanization affects the seasonal dynamics of photosynthesis and total yearly primary production. We examine transformed land cover types around large metropolitan areas, compare them to their lesser-urbanized or non-urbanized counterparts, and we make a continental scale assessment of productivity for three classes of urbanization. The relative impact to photosynthetic production is measured by observing the change in the normalized difference vegetation index (NDVI) as a function of the degree of urbanization. 


\section{METHODS}

We used a combination of satellite data, information extraction techniques, and geo-spatial data from map and tabular sources to carryout the analysis. Nighttime images from the Defense Meteorological Satellite's Operational Linescan system were used to create a thematic map portraying the extent and spatial distribution of urbanized, peri-urban, and non-urban areas in the coterminous United States. A digital land cover map generated by the United States Geological Survey (USGS) was used to define "pre-urban" land cover types and photosynthetic productivity was estimated using monthly maximum normalized difference vegetation index (NDVI) values from AVHRR data. The data sets were co-registered and staged in a geographic information system (GIS) to intersect and analyze the parameters in a spatially explicit way (Fig. 1). Using the DMSP/OLS urban thematic map as a template, NDVI values were calculated within each land cover type both inside and outside urbanized areas. The difference in primary productivity between the urbanized and non-urbanized portions of each land cover type was calculated by integrating the NDVI values over time. Land cover specific analyses were carried out by examining the land surface parameters within $200 \times 200 \mathrm{~km}$ plots $\left(40,000 \mathrm{~km}^{2}\right)$ for seven major cities in the coterminous United States. The approximate centroid of each city was located in the center of the sample plot so that urban, peri-urban, and non-urban areas were included in each plot around the cities.

A continental scale view of the impact of urbanization on photosynthesis was achieved by grouping the land cover classes together and comparing the different NDVI based productivity measurements for urbanized, peri-urban, and non-urban lands for all of the pixels in the coterminous U.S. 


\section{A. Mapping Urbanized Lands from Space}

There is no internationally standardized definition of "urbanized land" and map data representing this form of land cover at regional or super-regional scales are rare. As such, there is need of a methodology for identifying urban land use and mapping it synoptically. We used nighttime images from Defense Meteorological Satellite Program's Operational Linescan System to create the urban map for this study. Originally designed to map moon-lit cloud cover for nighttime aircraft navigation and weather forecasting for the United States Air Force, the DMSP/OLS operates at extreme sensitivity collecting image data at a moderate spatial resolution $(2.7 \mathrm{~km}$ pixel) across a broad vis-NIR band (.4 to $1.1 \mu \mathrm{m})$. The resulting images show a dramatic picture of urbanization through the detection of city lights during cloud free acquisitions [10]. Previously, DMSP/OLS data have been used to estimate population [11] and indicate energy consumption $[12,13]$.

The DMSP/OLS data used in this study were collected from October 1, 1994 - March 31, 1995, between 20:30 and 21:30 local time. The data were screened for cloud cover and ephemeral light sources, and re-projected onto a $1 \mathrm{~km}$ grid to conform with other global data bases [14]. These are composite data containing dozens of "hits" for each grid cell over the six month long acquisition period. The DN for each $1 \mathrm{~km}$ cell is a percentage representing the frequency of illumination for that cell (i.e. the number of times the cell was registered as lit divided by the sum of the OLS acquisitions for that cell). Using previously developed thresholding techniques, reasonably accurate maps showing urban core areas, peri-urban, and non-urban lands were generated based on the percentage of time a grid location was registered as lit during the data 
collection period (See Imhoff et al. [15] for a detailed description of this process and accuracy assessment).

A thematic product identifying three classes of urban land use was generated from the DMSP/OLS data: 1) Urbanized, 2) Peri-urban, and 3) Non-urban land. Urbanized areas exhibited high levels of nighttime light emission (>89\%); Peri-urban areas exhibited considerable but unstable illumination (5-88\%); and Non-urban lands were never observed as being lit $(<5 \%, 5 \%$ being considered noise [14] indicating no or little development. These classes and their areas compare well with census data estimating urban and non-urban areas in the United States [15]. Demographic parameters such as population and housing density were indexed to the DMSP/OLS map product by overlaying it with digital census data in the GIS $[16,17]$. Using the aggregate average (i.e., all seven urban study plots combined) the Urbanized land class had an area-weighted average population density of 1064 persons and 445 housing units per square kilometer, the Peri-urban Land class had 100 persons and 38 housing units per square kilometer, and the Non-urban Land class had an average of 14 persons and 5 housing units per square kilometer. A table showing the average population and housing densities associated with each of the urban areas featured in this article can be found in Table I.

\section{B. Pre-Urban Land Cover Determination}

For part of our assessment of the impact of urban land transformation on photosynthetic production we constrained the analysis by comparing changes within a land cover class. This was done to limit the possibility that the land use change signal would be lost or confounded by differences between land cover classes. We used the United States Geological Survey's North 
America Seasonal Land Cover Regions land cover classification to define land cover types for our analysis. This map is part of the North American Land Cover Characteristics Data Base and cover types are identified, in part, by their temporal spectral characteristics using 1-km AVHRR data. The Seasonal Land Cover Regions Map was chosen because it defines 205 land cover classes for the United States providing greater resolution than it's IGBP or Global Ecosystems counterparts [18-20]. However, the classification is hierarchical in nature and all of the Seasonal Land Cover types can be identified in the IGBP system. The North America Seasonal Land Cover Regions land cover classification is well suited for this analysis because it defines a large number of classes based primarily on vegetation type but contains no distinct "urban" land cover class. The large number of land cover classes and the absence of a distinct urban class provided the best possible "pre-urban" land cover view for our analysis.

\section{Estimating Photosynthetic Production via Satellite}

Data from the National Oceanic and Atmospheric Administration's polar-orbiting advanced very high resolution radiometer (AVHRR) sensor can be used to produce a vegetation index directly related to chlorophyll density contained on land [21-26]. The normalized difference vegetation index (NDVI) is expressed as [(Channel 2 - Channel 1$) /($ Channel $2+$ Channel 1)], where Channel 1 records reflected light from $0.55-0.70 \mu \mathrm{m}$ and Channel 2 records reflected light from 0.72-1.1 $\mu \mathrm{m}$. Previous studies have shown that the index is an accurate estimate of absorbed photosynthetically active radiation [27,28] and is strongly correlated to biomass [29-31].

In this study, a $1 \mathrm{~km}$ AVHRR composite data set of monthly maximum NDVI acquired from April 1992 through March 1993 was used to estimate photosynthetic production. The 
compositing process minimizes atmospheric effects, scan angle effects, cloud contamination, and solar zenith angle effects [32]. By integrating over time, monthly maximum NDVI data from AVHRR composites have been shown to be useful for estimating the annual and semi-annual primary productivity of vegetation on land [33-36].

To assess the impact of urban land transformation on productivity, a three-way merge was accomplished in the GIS where the land cover map was overlain on the NDVI composite, and the DMSP/OLS urban map was applied as a final layer. Every pixel in the merged data set had fifteen attribute values associated with it:

1) urbanization class from the DMSP data,

2) land cover type from the USGS land cover map, and

3) maximum NDVI values for each of the twelve months of the composite year from the AVHRR data set.

A mean urbanized and non-urbanized NDVI value was then computed for each land cover class (and for each month) by averaging all of the pixels inside and then outside the urbanized areas defined by the DMSP/OLS layer. The average monthly maximum NDVI values were multiplied by the number days in the month to produce units of NDVI*days. Summed over the year this measure has been used to represent annual primary production (see Prince [34] and Prince and Goward [35] for a more detailed description of this method of evaluation). A temperature threshold, using the thermal channel on the AVHRR (Channel 5, 11.5-12.5 $\mu \mathrm{m}$ ), was used to identify pixels where the mean monthly temperature was at or below $0^{\circ} \mathrm{C}$. NDVI's for these pixels were assigned a value of 0 as relatively little photosynthesis occurs at these temperatures. 
A set of NDVI*day signatures covering a period of one year were then generated for each cover type showing the differences inside and outside the urbanized zones.

\section{RESULTS}

\section{A. Urban Impact Signatures}

By combining the three data sets in a GIS we were able to generate comparative signatures of photosynthetic productivity for each land cover class as they exist inside and outside the urbanized areas as defined by the nighttime DMSP/OLS data. The results indicate that the impact of urbanization on photosynthetic production depends on two primary factors: the type or density of development, and the climatic/physiographic environment. Although the analysis was performed on over 100 cover types existing in and around seven large metropolitan areas in the US, four primary patterns of the seasonal dynamics of the impact of urbanization on productivity appeared repeatedly in the data (Table II).

1) Continuously lower photosynthetic production in the urbanized portion of the land cover type (Fig. 2),

2) Extended growing season in the urbanized areas resulting in higher productivity at the beginning and end of the growing season and lower peak season productivity (Figs. 3 and 4).

3) Higher productivity in the urbanized areas throughout the year (Fig. 5), and

4) Higher productivity in the urbanized areas during a resource limited part of the seasonal cycle but lower yearly summed productivity (Fig. 6). 
Continuously lowered productivity in urbanized areas was found for numerous cover types around all the metropolitan areas researched in this study. This effect is common for heavily urbanized land cover types and is well represented by a Savanna land cover type found around Miami, Florida (Fig. 2). This land cover type has been heavily used for urban development in south Florida. With the exception of deep winter, the productivity of the urbanized portion of this land cover class was reduced more or less uniformly throughout the year resulting in a summed loss of $22.4 \mathrm{NDVI}^{*}$ days for the year. This pattern is most likely the result of intense urbanization where a substantial portion of the vegetation in the urbanized area has been converted to impervious surfaces supporting roads and other infrastructure. These surfaces are nearly devoid of plant species and will substantially lower the monthly maximum NDVI calculated for these areas [37].

The second pattern, which is characterized by an extended growing season in urbanized areas, was found to be common for numerous cover types in seasonally cool or cold parts of the United States. In fact this pattern was the most commonly repeated signature for all of the cover types we studied. Urbanized areas within these cover types show an earlier start of photosynthesis in the spring, a lower peak production, and a slower reduction at the end of the growing season. Occasionally mid-winter photosynthetic activity was also observed in these areas possibly due to a heat island effect. The yearly impact of urbanization in these areas is variable, some demonstrating a net loss, others showing a net gain in productivity.

Examples of this pattern can be seen in two Mixed Forest cover types around Chicago, Illinois. The forest cover type in Fig. 3 (Mixed Forest \#1) is composed largely of Aspen, Maple, Oak, 
Pine, and Spruce and the forest cover type in Fig. 4 (Mixed Forest \#2) is composed of Maple, Beech, Birch, and Pine. In both cases, productivity in the urbanized portion of the land cover class is enhanced from March through June, reduced relative to the non-urbanized areas from July through September, and slightly higher again in the winter months. Both exhibit rapid declines in productivity with the onset of Autumn (October-November). We interpret these trends to result from a combination of urban heat island effect and the cultivation of grasses and shrubs in lower-density urbanized areas. This compensated for the negative effect of urbanization on productivity if development is not too intense. Higher temperatures would prolong the growing season for the grasses and shrubs in this cover type while the reduced peak season is again due to higher percentage of impervious non-vegetated surfaces.

However, the net yearly effect of urbanization on the productivity of the two forests is quite different: the Aspen-Maple-Oak forest showed a yearly loss of productivity (5.56 NDVI*days) while the Maple-Beech forest showed an increase in productivity (4.29 NDVI*days). The rapid fall off of productivity for both urban and non-urban zones in autumn indicated a substantial population of deciduous trees and shrubs in both areas. We speculate the higher urban productivity in the winter could indicate a composition change in vegetation cover type, from mixed forest to a higher incidence of planted grasses and evergreen shrubs.

The third and fourth patterns are similar to one another in that both occurred in semi-arid, arid, or seasonally-arid regions where the urbanization is not too intense. These patterns show an enhancement of productivity inside the urbanized areas, especially during the warmer months, and sometimes throughout the year. We attribute the increased productivity to irrigation and the 
âteration of natural land cover by cultivation of introduced plant species. For example, the Open Shrubland land cover type in and around Denver, Colorado exhibited higher productivity in the urbanized area as compared to natural land cover through most of the year indicating conversion of natural semi-arid land cover to one of irrigated grasses, shrubs, and trees (Fig. 5). In this case, the urbanized portions of this land cover class gained a yearly sum of 10.73 NDVI*days over the non-urbanized areas.

A fourth "Mediterranean" pattern was found for land cover types around urban centers along the West Coast of the United States which experience cool-wet winters and hot-dry summers. Higher productivity was found in the urbanized parts of the land cover class during the dry summer season but during the wet winter season the productivity in the non-urban areas greatly exceeds that of the urbanized part. This pattern is well expressed in a Woody Savanna land cover type around Sacramento, California (Fig. 6). During the months from May-December, the dryer warmer season, the urbanized areas in this land cover class gained $4.86 \mathrm{NDVI}^{*}$ days over the non-urbanized area. However, in the cool wet season, from January through April, the nonurbanized portions of the land cover type gained 8.9 NDVI*days over the urbanized areas. The yearly summation showed a loss of $4.0 \mathrm{NDVI} *$ days due to urbanization. The increased productivity of the urbanized areas in the dry season is thought to be a result of irrigation. However, the rapid fall off and overall reduced productivity of the urbanized area in the winter wet season could be due to various factors. An increased proportion of impervious surfaces in the urbanized areas could explain this pattern but the replacement of native evergreen species with exotic deciduous species of trees and shrubs, which go dormant in the winter (wet) season, could also contribute to this pattern. 


\section{B. Continental Scale View}

We created a continental scale view of the impact of urbanization on photosynthesis by calculating the average monthly maximum NDVI for all the land area in the coterminous United States for the three classes of urban land as defined by the DMSP/OLS data. The analysis resulted in a quantification of the seasonal pattern of productivity for all of the vegetation land cover types in Urbanized, Peri-urban, and Non-urban areas (Fig. 7, Table III). This aggregate approach revealed the relationship between land use in the United States and photosynthetic production. The land surface with the highest productivity was found in the Peri-urban areas. The summed yearly production for the Peri-urban land area was 135.3 NDVI*days, or 10 NDVI*days longer than the Urbanized Lands (125.3 NDVI*days for Urbanized Lands). The Peri-urban lands in the U.S. contain some of the most productive soils [9] and are frequently still in agricultural use or remain as secondary forest. These areas support the highest photosynthetic productivity in the United States and are directly in the path of urban expansion.

Perhaps the greatest surprise was the low productivity calculated for lands in the Non-urban class. The Non-urban class had a yearly summed productivity of $117 \mathrm{NDVI}{ }^{*}$ days - that is 18.3 NDVI*days shorter than the Peri-urban class and $8.3 \mathrm{NDVI} *$ days shorter than the Urban class. This is primarily because the Non-urban class, defined by a nearly complete absence of illumination at night, contains vast areas of resource-limited lands in deserts, high altitude montane environments, wetlands, beaches, and rocky or degraded land. Human activity is limited in these areas by the same resource limitations that drive other biological systems. It is interesting to note that, despite the aggregation of land cover types in the continental scale 
analysis, the time behavior of photosynthesis for the Urbanized land and Non-urban land was very similar to the extended growing season dynamic seen for various individual cover types as described above.

\section{CONCLUSIONS}

We quantified the effects of urban land transformation upon photosynthetic production through a multi-level, geo-spatial analysis of nighttime and daytime satellite data, land cover maps, and ancillary census information. The effects of urban land transformation on productivity are variable, depend on the degree of urban land transformation and the climatic/physiographic settings. In general, urbanization appears to lower the overall photosynthetic productivity of the landscape. While irrigation and urban heat islands may offset the effects of increasing the area of impervious surfaces, the overall trend is toward reduced yearly photosynthetic productivity in the urbanized zones. Viewed at the continental scale, urbanization resembles other biological processes: growth originates where resources are concentrated; uses available resources; and diminishes where resources are limited. The clear trend is that the most productive land (periurban land) is directly in the path of urbanization. On average, we can assume that the transformation from peri-urban to urban will result in an annual loss of about 10 NDVI*days of photosynthetic production. Overall, about $3 \%$ of the land surface of the United States is now urbanized and about $15 \%$ of the land surface is in the peri-urban class. What the overall affect of the continuing process of urbanization will be on the aggregated photosynthetic production potential of the continent remains to be considered. 


\section{REFERENCES}

1. R. W. Kates, B. L. Turner, II, and W. C. Clark, in The Earth Transformed by Human Action, B.L. Turner, Ed. (Cambridge University Press, Cambridge, U.K., pp. 1-17, 1990.

2. P. Ehrlich and A. Ehrlich, "The value of biodiversity," Ambio 21, p. 219, 1992.

3. G. C. Daily, and P. R. Ehrlich, "Population, sustainability, and Earth's carrying capacity," BioScience 42, p. 761, 1992.

4. P. M. Vitousek, H. A. Mooney, J. Lubchenco, and J. M. Melillo, " Human domination of Earth's ecosystems," Science.277, p. 494, 1997.

5. P.M. Vitousek, P. Ehrlich, A. Ehrlich, and P. M. Matson, P.M., "Human appropriation of the products of photosynthesis," BioScience $36(6)$, p.368, 1986.

6. V. Keilis-Borok, Self-Destruction of Megacities: Challenge and Responsibilities of IUGG, Report to the IUGG Committee for The International Decade for Natural Disaster Reduction, 18-22 July 1994, Boulder CO, 1994.

7. M. Wackernagel and D. Yount, "The ecological footprint: An indicator of progress toward ecological sustainability," Environmental Monitoring and Assessment (51), p. 511 Kluwer Academic Publishers, Netherlands, 1998.

8. C. Folke, A. Jannson, J. Larsson,. and R. Costanza, "Ecosystem Appropriation by Cities," Ambio 26(3), p. 100, 1997.

9. M. L. Imhoff, et al., "Using nighttime DMSP/OLS images of city lights to estimate the impact of urban land use on soil resources in the U.S.," Remote Sensing Env. 59, pp. 105$117,1997$.

10. T. A. Croft, "Nighttime Images of the Earth From Space", Scientific American 239(1), p. 86, 1977.

11. P. Sutton, D. Roberts, C. Elvidge, and H. Meij, "A comparison of nighttime satellite imagery and population density for the continental United States," Photogram. Eng, Remote Sensing 63, p.1303, 1997.

12. R. Welch, and S. Zupko, "Urbanized area energy patterns from DMSP data," Photogram. Eng, Remote Sensing 46( 2), p. 201, 1980. 
13. C. Elvidge, K. Baugh, E. A. Kihn, H. W. Kroehl, and C. Davis, 'Relation between satellite observed visible near infrared emmissions, population, and energy consumption, "Int. J. Remote Sensing 18, p.1373,1997.

14. C. Elvidge, K. Baugh, E. A. Kihn, H. W. Kroehl, and C. Davis, "Mapping of city lights using DMSP Operational Linescan System data," Photogram. Eng, Remote Sensing 63, p. $727,1997$.

15. M. L. Imhoff, W. T. Lawrence, D. C. Stutzer, and C. D. Elvidge, "A technique for using composite DMSP/OLS "city lights" satellite data to accurately map urban areas," Remote Sensing Environment 61, pp. 361-370, 1997.

16. U.S. Bureau of the Census, Topologically Integrated Geographic Encoding and Referencing System (TIGER) Line Files (U.S. Dept. of Commerce, Economic and Statistics Administration, Washington, D.C., 20233, 1992.

17. U.S. Bureau of the Census, Summary Tape File 1B, 1990 Census of Population and Housing (US Dept. of Commerce, Economic and Statistics Administration, US Government Printing Office, Washington, D.C. 20233, 1991.

18. T. R. Loveland, and A. S. Belward, "The IGBP-DIS global land cover data set DISCover: first results," Int. J. Remote Sensing 18: (15), p. 329, 1997.

19. T. R. Loveland, and A. S. Belward, "The International Geosphere Biosphere Program and Information System global land cover data set (DISCover)," Acta Astronautica 41 (4-10), p. 68, 1997.

20. J. S. Olson, Global ecosystem framework-definitions, (USGS EROS Data Center Internal Report, Sioux Fall, SD, 37 p. 1994.

21. J. L. Monteith, "Climate and the efficiency of crop production in Britain," Phil. Trans. Royal Soc. B-281, p. $277,1977$.

22. C. J. Tucker, "Red and photographic infrared linear combinations for monitoring vegetation," Remote Sensing of Environ. 8(2), pp.127-50, 1979.

23. P. J. Curran, "Multi-spectral remote sensing for the estimation of green leaf area index," Phil. Trans. Royal Soc. A309, p. 257, 1983.

24. C. S. T. Daughtry, K.P. Gallo, and M.E. Bauer, "Spectral estimates of solar radiation intercepted by corn canopies," Agron. J. 75, p. 527, 1983.

25. J. L. Hatfield, G. Asrar, and E. T. Kanemasu, "Intercepted photosynthetically active radiation in wheat canopies estimated by spectral reflectance," Remote Sensing Environ. 14, p. 65, 1984. 
26. P. J. Sellers, "Canopy reflectance, photosynthesis and transpiration," Int. J. Remote Sensing 6, pp. 1335-1372, 1985.

27. G. S. Asrar, M. Fuchs, E. T. Kanemasu, and J. L. Hatfield, "Estimating absorbed photosynthetically active radiation and leaf area index from spectral reflectance in wheat," Agron. J., 76, pp.300-306, 1984.

28. G. Asrar, E. T. Kanemasu, G. P. Miller, and R. L. Weiser, "Light interception and leaf area estimates from measurements of grass canopy reflectance," IEEE Transactions Geoscience Remote Sens. GE24, pp. 76-82, 1986.

29. C.J. Tucker, B.N. Holben, J.H. Elgin, and J.E. McMurtrey, "Remote sensing of total dry matter accumulation in winter wheat," Remote Sensing Environment 11, p.171, 1981.

30. C.J., Tucker, C.L. Vanpraet, M.J. Sharman, and G. Van Ittersum,"Satellite remote sensing of total herbaceous biomass production in the Senegalese Sahel: 1980-1984," Remote Sensing Environment 14, pp. 233-249, 1985.

31. G. Asrar, E.T. Kanemasu, R.D. Jackson, and P.J. Pinter, "Estimation of total above ground phytomass production using remotely sensed data," Remote Sensing Environ., 17, pp. 211-220, 1985.

32. B. N. Holben, "Characteristics of maximum-value composite images for temporal AVHRR data ," Int. J. Remote Sensing 7, pp. 1435-1445, 1986.

33. C. J. Tucker, and P.J. Sellers, "Satellite remote sensing of primary production," Int. J. Remote Sensing 7, p. 1395, 1986.

34. G. Gosse, et al., "Production maximale de matière sèche et rayonnement solaire intercepté par le végétal," Agronomie 6, p. 47, 1986.

35. S. D. Prince, "A model of regional primary production for use with coarse resolution satellite data," Int. J. Remote Sensing 12, pp. 1313-1330, 1991.

36. S. D. Prince and S. Goward,"Global primary production: a remote sensing approach," $J$. Biogeography 22, p. 815, 1995.

37. M. K Ridd, "Exploring a V-I-S (vegetation-impervious surface-soil) model for urban ecosystem analysis through remote sensing: comparative anatomy for cities," Int. J. Remote Sensing 12, pp. 2165-2185, 1995. 
TABLE I

MEAN POPULATION AND HOUSING DENSITY FOR URBAN RELATED CATEGORIES DERIVED FROM THE DMSP/OLS DATA

\begin{tabular}{|c|c|c|}
\hline & Population Density (persons $/ \mathbf{k m}^{2}$ ) & Housing Density (housing units $/ \mathrm{km}^{2}$ ) \\
\hline $\begin{array}{l}\text { Miami } \\
\text { Non-urban } \\
\text { Urbanized }\end{array}$ & $\begin{array}{c}3.5 \\
1034.6\end{array}$ & $\begin{array}{c}1.4 \\
477.2\end{array}$ \\
\hline $\begin{array}{l}\text { Chicago } \\
\text { Non-urban } \\
\text { Urbanized }\end{array}$ & $\begin{array}{c}18.9 \\
1263.4\end{array}$ & $\begin{array}{c}7.0 \\
490.1\end{array}$ \\
\hline $\begin{array}{l}\text { Denver } \\
\text { Non-urban } \\
\text { Urbanized }\end{array}$ & $\begin{array}{c}4.7 \\
923.9\end{array}$ & $\begin{array}{c}2.2 \\
441.9\end{array}$ \\
\hline $\begin{array}{l}\text { Sacramento } \\
\text { Non-urban } \\
\text { Urbanized }\end{array}$ & $\begin{array}{c}13.2 \\
1147.8\end{array}$ & $\begin{array}{c}5.7 \\
461.7\end{array}$ \\
\hline $\begin{array}{l}\text { USA Total * } \\
\text { Non-urban } \\
\text { Peri-urban } \\
\text { Urbanized }\end{array}$ & $\begin{array}{c}13.7 \\
100.0 \\
1063.7\end{array}$ & $\begin{array}{c}5.4 \\
38.3 \\
445.1\end{array}$ \\
\hline
\end{tabular}

* USA Total is the aggregated average of $200 \times 200 \mathrm{~km}$ plots around seven cities (Denver, CO; Chicago, IL Miami, FL; Sacramento, CA, San Francisco, CA; Seattle, WA; Washington D.C.). Demographic values from 1990 census. 
TABLE II

TEMPORAL SUMS OF NDVI (NDVI*DAYS) FOR FIVE LAND COVER TYPES AROUND MAJOR URBAN AREAS IN THE UNITED STATES.

\begin{tabular}{|c|c|c|c|c|c|c|c|c|c|c|c|c|c|c|}
\hline Pattern & IGBP Land Cover & $\begin{array}{l}1992 \\
\text { Apr }\end{array}$ & May & Jun & Jul & Aug & Sept & Oct & Nov & Dec & $\begin{array}{l}1993 \\
\text { Jan }\end{array}$ & Feb & Mar & SUM \\
\hline \multirow[t]{3}{*}{ I } & $\begin{array}{l}\text { Savanna } \\
\text { Miami, Florida }\end{array}$ & & & & & & & & & & & & & \\
\hline & Urbanized & 11.76 & 11.04 & 9.30 & 13.27 & 13.36 & 12.79 & 12.21 & 11.31 & 13.02 & 11.47 & 11.45 & 13.24 & 144.22 \\
\hline & Non-Urban & 12.51 & 14.35 & 13.50 & 15.10 & 15.72 & 15.42 & 15.13 & 13.92 & 14.88 & 11.16 & 10.39 & 14.54 & 166.61 \\
\hline \multirow[t]{3}{*}{ II } & $\begin{array}{l}\text { Mixed Forest \#1 } \\
\text { Chicago, Illinois }\end{array}$ & & & & & & & & & & & . & & \\
\hline & Urbanized & 7.99 & 16.27 & 17.62 & 19.31 & 17.98 & 18.38 & 17.67 & 4.94 & 6.45 & 6.87 & 5.14 & 5.89 & 144.52 \\
\hline & Non-Urban & 7.32 & 13.27 & 16.21 & 20.25 & 19.72 & 20.13 & 17.45 & 4.55 & 5.00 & 6.13 & 5.11 & 5.11 & 140.22 \\
\hline \multirow[t]{3}{*}{ II } & $\begin{array}{l}\text { Mixed Forest \#2 } \\
\text { Chicago, Illinois }\end{array}$ & & & & & & & & & & & & & \\
\hline & Urbanized & 9.05 & 15.65 & 15.99 & 17.85 & 17.16 & 17.26 & 17.01 & 5.19 & 6.82 & 6.13 & 5.06 & 6.36 & 133.16 \\
\hline & Non-Urban & 8.57 & 13.71 & 14.90 & 20.29 & 20.29 & 20.50 & 17.22 & 5.25 & 5.80 & 5.89 & 6.16 & 6.51 & 138.57 \\
\hline \multirow[t]{3}{*}{ III } & $\begin{array}{l}\text { Open Shrubland } \\
\text { Denver, Colorado }\end{array}$ & & & & & & & & & & & & & \\
\hline & Urbanized & 6.34 & 6.71 & 10.01 & 9.05 & 8.93 & 8.81 & 6.94 & 6.26 & 4.01 & 5.13 & 4.15 & 4.19 & 80.52 \\
\hline & Non-Urban & 5.35 & 5.36 & 9.02 & 7.96 & 7.96 & 7.95 & 8.05 & 5.31 & 2.16 & 3.61 & 2.95 & 4.11 & 69.79 \\
\hline \multirow[t]{3}{*}{ IV } & $\begin{array}{l}\text { Woody Savanna } \\
\text { Sacramento, California }\end{array}$ & & & & & & & & & & & & & \\
\hline & Urbanized & 13.38 & 9.77 & 8.07 & 8.43 & 7.42 & 7.31 & 7.09 & 7.65 & 4.37 & 9.72 & 7.96 & 12.01 & 103.17 \\
\hline & Non-Urban & 17.09 & 9.93 & 7.47 & 7.31 & 6.21 & 6.08 & 5.94 & 7.30 & 4.99 & 10.98 & 9.71 & 14.19 & 107.20 \\
\hline
\end{tabular}

Statistics were gathered within $200 \times 200 \mathrm{~km}$ plot around each city.

Mean monthly maximum NDVI values were calculated inside and outside the urbanized areas for each cover type. A cold mask based on AVHRR channel 5 data was used to factor out pixels with temperature 0degress $\mathrm{C}$ or less.

TABLE III.

TEMPORAL SUMS OF NDVI (NDVI*DAYS) FOR ALL LAND IN THE UNITED STATES DIVIDED INTO THREE CLASSES OF URBANIZATION BASED ON DMSP/OLS DATA.

\begin{tabular}{|llllllllllllll|}
\hline & 1992 & & \multicolumn{1}{c|}{1993} \\
DMSP Classification & \multicolumn{1}{c|}{ Apr } & May & Jun & Jul & Aug & Sept & Oct & Nov Dec & Jan & Feb & Mar & Sum \\
Urbanized Land & 10.16 & 12.38 & 12.51 & 13.10 & 12.61 & 12.46 & 11.99 & 8.83 & 8.64 & 8.05 & 6.85 & 7.76 & 125.35 \\
Peri-urban Land & 10.41 & 13.24 & 14.09 & 15.35 & 14.65 & 14.23 & 12.67 & 8.86 & 8.78 & 8.53 & 6.90 & 7.59 & 135.29 \\
Non-urban Land & 9.16 & 11.43 & 12.45 & 13.53 & 12.26 & 11.91 & 10.95 & 7.53 & 7.68 & 7.92 & 5.80 & 6.41 & 117.03 \\
\hline
\end{tabular}

Mean monthly maximum NDVI values were calculated for each urban class. A cold mask based on AVHRR channel5 data was used to factor out pixels with temperature $0^{\circ} \mathrm{C}$ or less. The urbanized, peri-urban, and non-urban lands represents approximately 3,15 , and $82 \%$ of the total surface area of the continental U.S. respectively. 


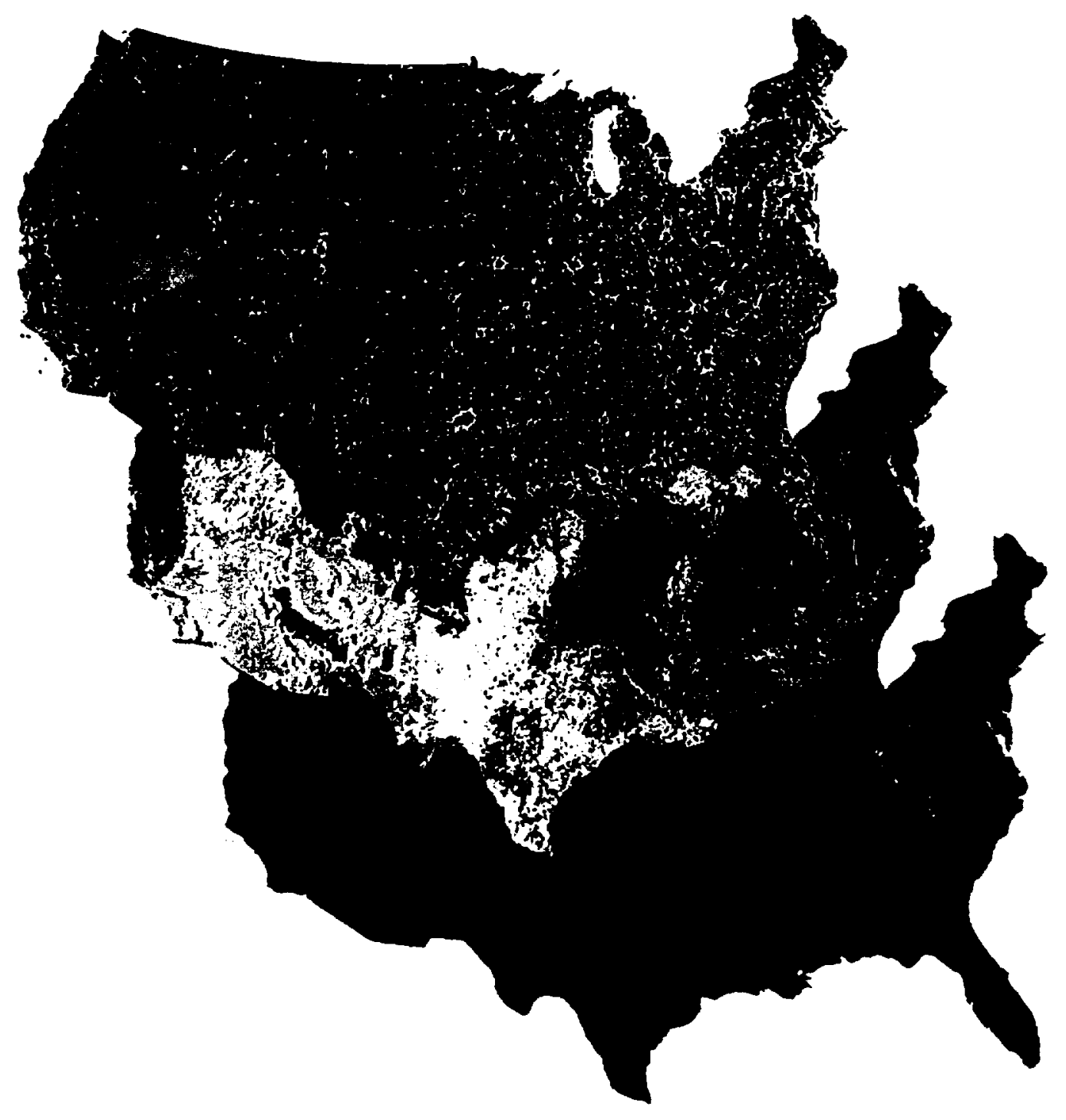

Figure 1. The geospatial data used in this study. (Top) An urban classification map based on DMSP/OLS satellite data [15] showing three classes of land use: urbanized land (red), peri-urban land (yellow), and non-urban land (black). (Middle) The United States Geological Survey's North America Seasonal Land Cover Regions land cover map [18-20]. (Bottom) An NDVI image from the AVHRR satellite monthly maximum NDVI data set $[32,33]$. A single month (July) is shown as an example. The urban map, the land cover map, and the AVHRR data set were co-registered for analysis in a GIS. 


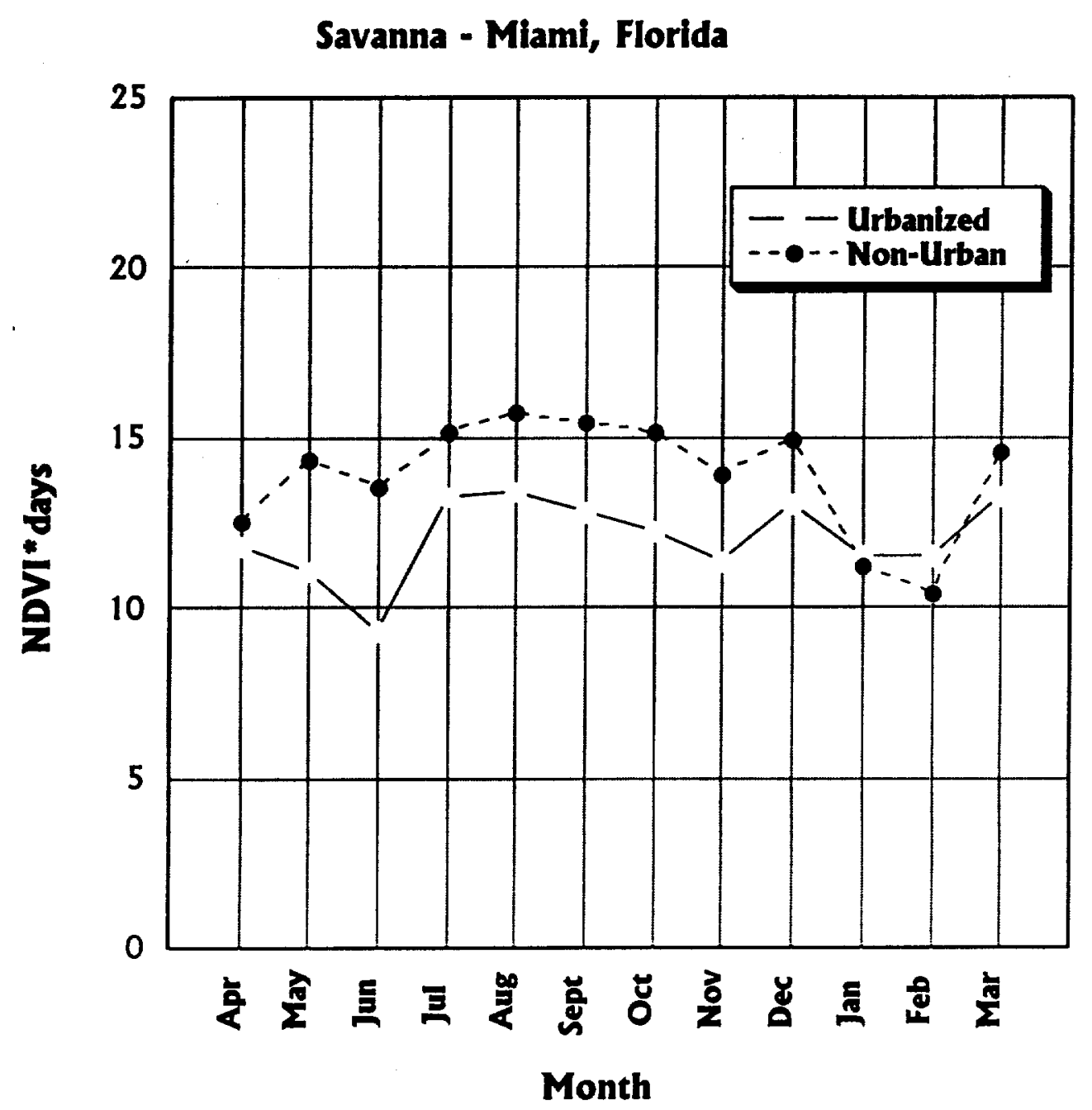

Fig. 2. Profile of photosynthesis for urban and non-urban areas in and adjacent to Miami, Florida. Paved surfaces result in lower aggregated photosynthetic production in the urbanized parts of the land cover class. 


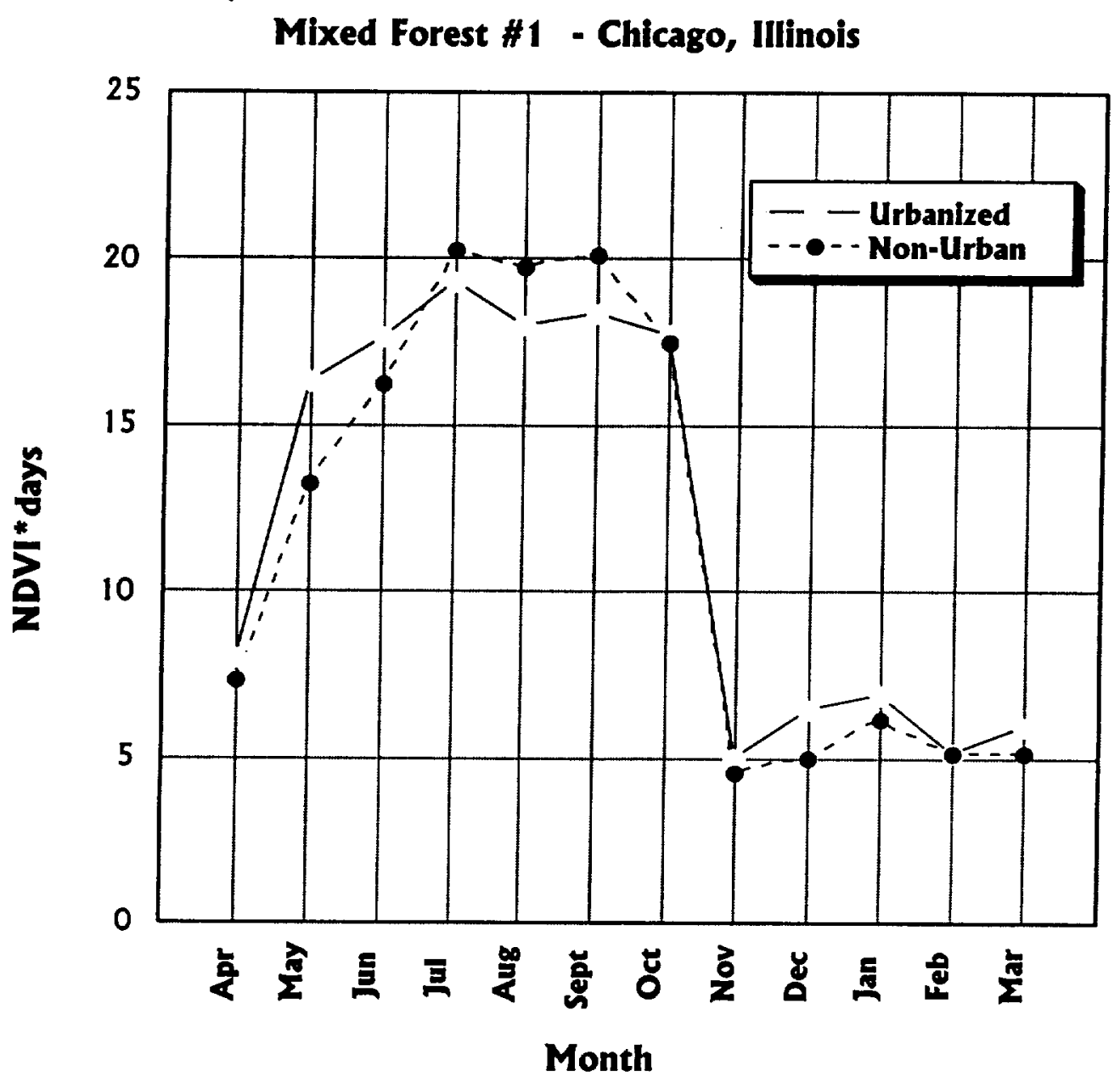

Fig. 3. Productivity signatures for urbanized and non-urbanized areas of a Mixed Forest cover type in the vicinity of Chicago, Illinois. This pattern was found most typically in seasonally cold geographic regions. Photosynthetic production starts earlier in the urbanized areas, has lower peak growing season productivity, and has higher production in the winter months. An urban heat island effect and the ecosystem alteration are probably responsible for the increased productivity in the urbanized areas which counter balances the negative effects of impervious surfaces. In this example, however, there was still a negative overall impact on productivity due to urbanization. The urbanized part of this land cover class had a net loss of $5.56 \mathrm{NDVI} *$ days relative to the non-urban part. 


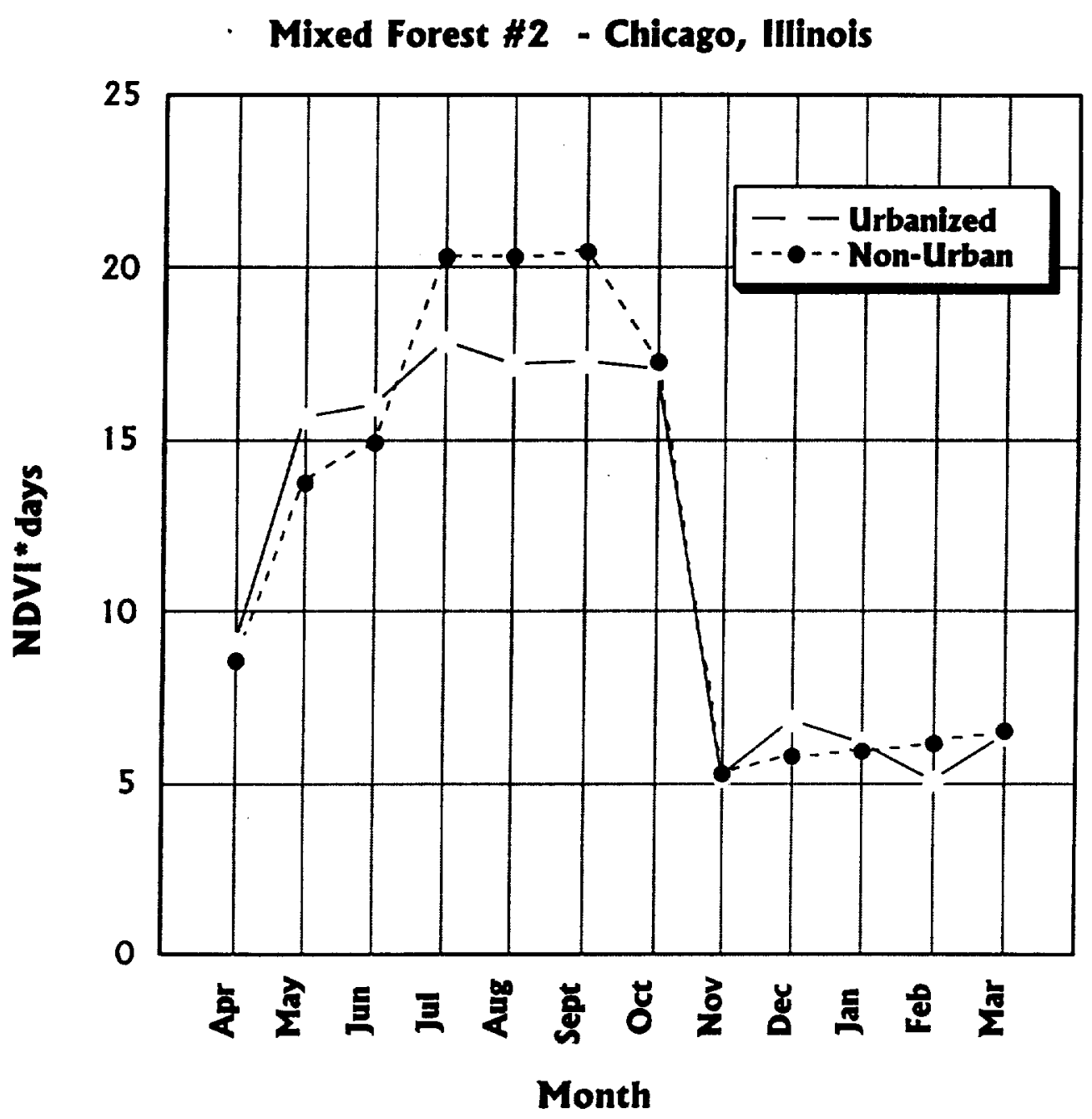

Fig. 4. Seasonal pattern for another Mixed Forest cover type around Chicago, Illinois. The pattern is very similar to one shown in Fig. 4, however, in this case, the yearly total productivity is greater in the urbanized area (net gain of $4.29 \mathrm{NDVI}^{*}$ days). The increase is attributed to the urban heat island and a higher incidence of planted grasses and evergreen shrubs in these areas. 


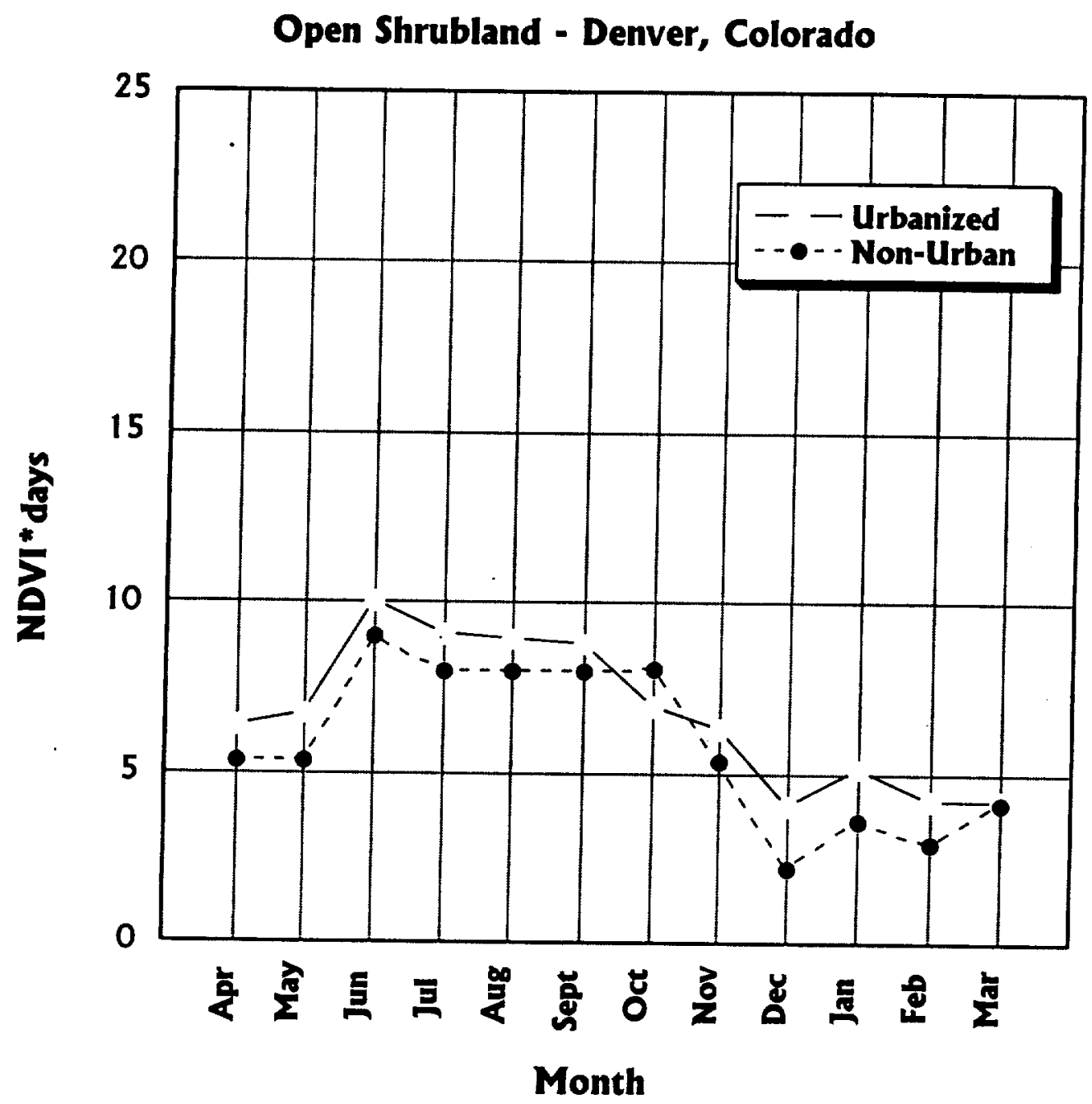

Fig. 5. Open Shrub Lands around Denver, Colorado show overall enhanced photosynthetic production in urbanized areas. The greater productivity in the urbanized portions of this cover type is probably due to replacement of native cover type with species supported with irrigation. 


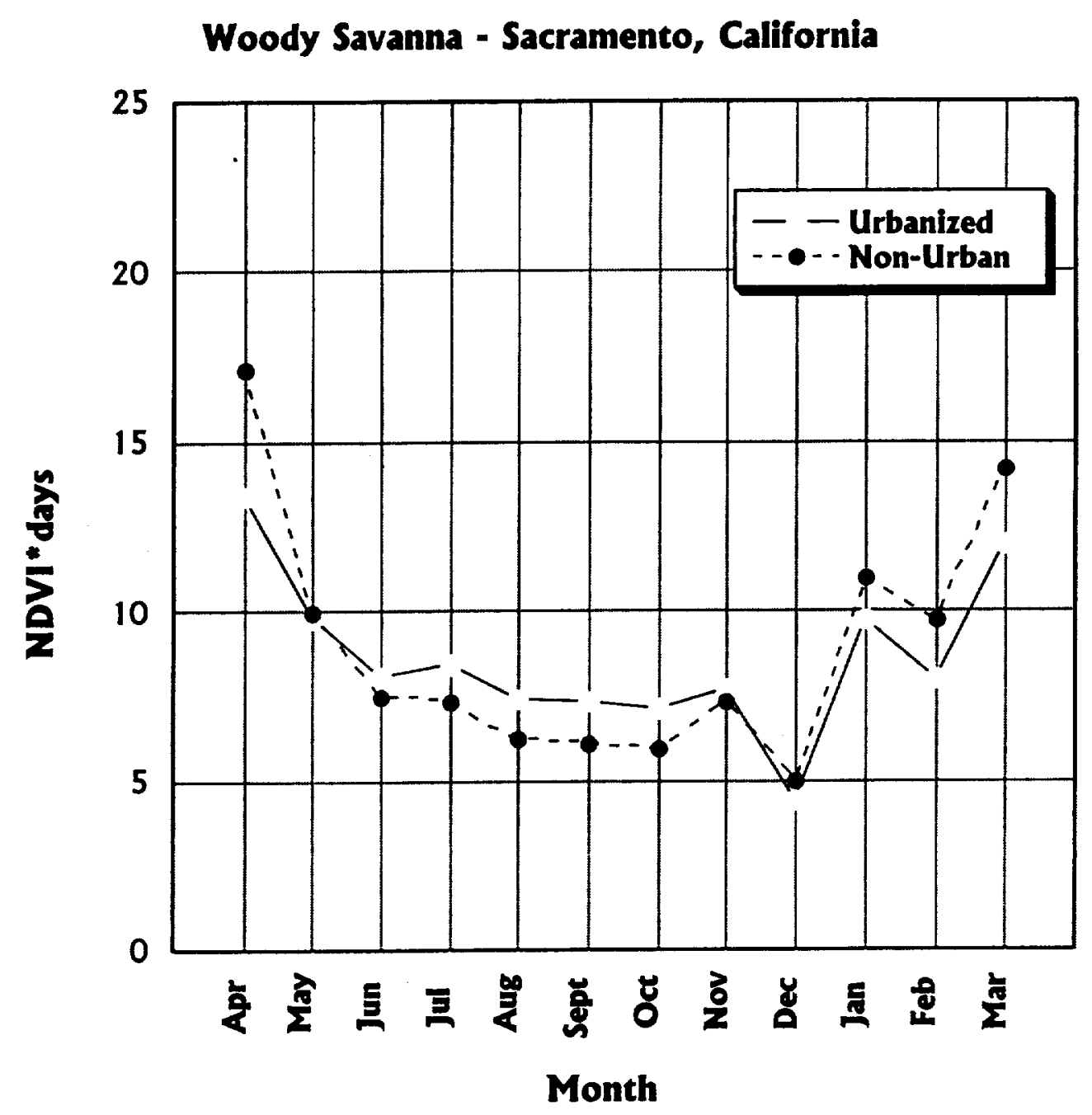

Fig. 6. Woody Savanna cover type around Sacramento, California showing a Mediterranean seasonal pattern. Irrigation and ecosystem alterations with exotic species may both contribute to the urban signal. Note higher productivity for urbanized areas in the peak dry months. This is almost certainly due to irrigation. In the winter- wet season, the exotic deciduous species in the urbanized areas go dormant reducing the NDVI of these areas. 


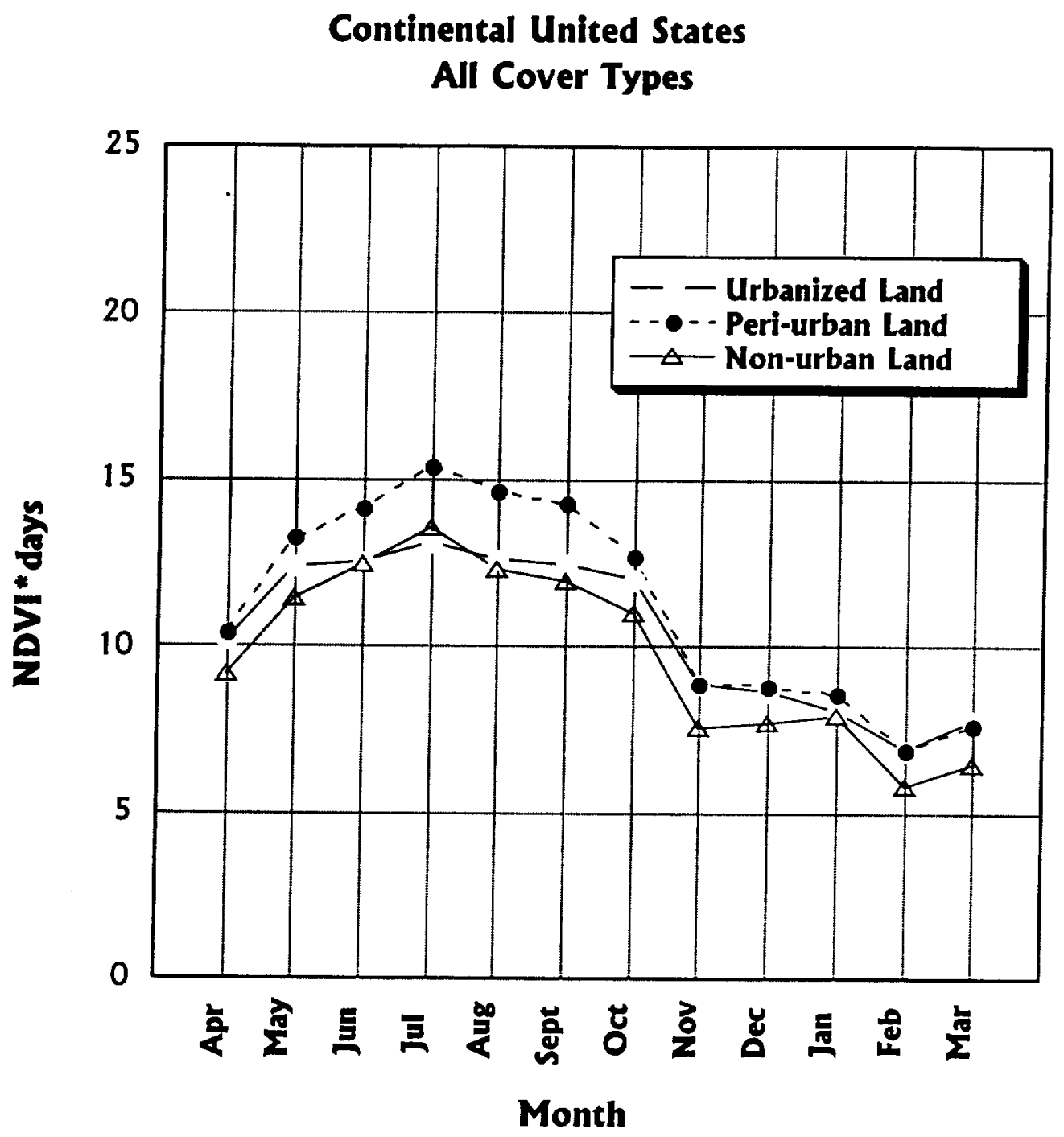

Fig. 7. Annual NDVI based productivity signatures for the three DMSP derived classes of urbanization for all of the surface area of the continental U.S. The value for each month is the mean NDVI*days calculated for all land cover types in each class of urbanization. 
